\title{
MODEL PENDIDIKAN KARAKTER DALAM MASYARAKAT JEPANG
}

\author{
Budi Mulyadi \\ Fakultas Ilmu Budaya Universitas Diponegoro \\ Email: budi_mulyadi09@yahoo.com
}

\begin{abstract}
This research entitled The Model of Character Education in Japanese society. The main goal of this research is to know how the model of character education in Japanase society is done. This research is combination between field and library research. Main methods are observation, interview, intepretation. There are unique character in Japanese society in which couldn't be found in other nations. Spirit of Bushido (discipline, honest, tough, work hard) is foundations of Japanese character. This such a character building is deserve to become an example to Indonesia. Japan shows us, they build character successfully. Japan become a developed modern nation without losing their core values and cultural.
\end{abstract}

Key word: Charakter Building, Japanese Society and culture, Bushido

\section{LATAR BELAKANG MASALAH}

Pendidikan karakter menjadi masalah yang sangat diperhatikan akhirakhir ini. Banyak lembaga pendidikan formal mulai dari tingkat sekolah dasar sampai tingkat perguruan tinggi mulai memperhatikan pendidikan karakter dan mencoba memasukan ke dalam kurikulum pendidikan. Hal ini terkait dengan masalahmasalah moral yang kerap terjadi di Indonesia. Masalah karakter menjadi sorotan seluruh rakyat Indonesia dalam dua dasawarsa terakhir ini. Masyarakat Indonesia dikejutkan oleh banyak hal yang memprihatinkan seperti korupsi, kerusuhan, kekerasan, konflik antar suku bangsa dan masalah yang lainnya.

Kesadaran untuk mengatasi masalah kemerosotan karakter bangsa ini muncul ketika sudah sampai pada kondisi kronis. Dalam kondisi seperti ini penanganan akan jauh lebih sulit. Masalah karakter adalah masalah mendasar. Karakter terbentuk dalam kurun waktu yang lama dan proses yang panjang. Upaya untuk merubah suatu karakter menjadi karakter tertentu seperti yang dinginkan merupakan hal sangat sulit. Kesulitan sebesar apapun harus tetap ditempuh dan dilalui jika kita semua ingin agar bangsa Indonesia tidak hancur. Pendidikan karakter itu merupakan proses panjang yang harus dilakukan drngan sabar, bertahap, berkelanjutan (Eko Budiardjo, makalah seminar nasional Revitalisasi Pancasila dalam Karakter Bangsa, 30 September 2010, FIB UNDIP )

Di tengah perkembangan kehidupan yang diwarnai dengan paradigma positivisme dalam segala bidang ini, masalah yang berkaitan dengan moral mental, spiritial, kultural dikesampingkan. Manusia lebih terfokus pada hal-hal yang bersifat fisis, materialis, ekonomis, rasionalis, pragmatis yang dapat terukur dengan pasti dengan hasil yang dapat dirasakan dan dilihat secara langsung.

Ada aspek yang sangat berpengaruh terhadap kemajuan suatu bangsa yaitu jiwa atau karakter bangsa. Suatu bangsa yang mempunyai keterbatasan SDA dan kondisi SDM yang belum baik, namun karena mempunyai jiwa dan karakter tertentu akan mampu menjadi bangsa yang unggul. Secara umum bangsa Jepang telah membuktikan secara nyata. Masyarakat Jepang sangat menyadari akan pentingnya landasan karakter yang baik bagi manusia dan masyarakat. Nilai moral, mental, spiritual masyarakat Jepang sangat dijunjung tinggi. Hal itu bisa dicapai dengan pendidikan karakter yang dilakukan dilembaga pendidikan formal. 
Bangsa Jepang telah sampai pada suatu capaian yang menakjubkan. Setelah restorasi Meiji Jepang dalam waktu yang tidak terlalu lama telah menjadi bangsa modern yang mampu mengejar kemajuan bangsa-bangsa Barat. Salah satu faktor yang menyebabkan bangsa Jepang menjadi bangsa yang maju karena mereka mempunyai keunggulan karakter yang tidak dimiliki oleh bangsa-bangsa lainnya di dunia.

Kerja keras, disiplin, sederhana, cinta tanah air merupakan beberapa karakter unggul yang dimiliki bangsa Jepang. Ada beberapa faktor yang menyebabkan Jepang menjadi bangsa yang berkarakter unggul, salah satunya adalah mereka sangat memperhatikan pendidikan karakter. Pendidikan karkater sangat diutamakan baik di lembaga formal maupun non formal. Dari sejak taman kanak-kanak sampai tingkat perguruan tinggi mereka memperoleh pendidikan karakater yang kemudian mereka terapkan dalam kehidupan seharihari mereka.

Dari latar belakang di atas penulis ingin meneliti lebih jauh tentang model pendidikan karakter yang diselenggarakan di lembaga formal di negara Jepang.

\subsection{Rumusan Masalah}

Rumusan masalah dalam penelitian ini adalah bagaimana cara pendidikaan karakter dalam masyarakat Jepang dilaksanakan.

\subsection{Tujuan Penelitian}

Tujuan dari penelitian ini untuk memaparkan tentang pelaksanaan pendidikan karakter dalam masyarakat Jepang

\subsection{Metode Penelitian}

Penelitian ini merupakan penelitian kombinasi antara penelitian studi pustaka dengan penellitian lapangan. Studi pustaka digunakan untuk membuat analisa terhadap masalah yang dikaji. Disamping itu beberapa buku sekaligus juga merupakan data sekunder. Berikut ini beberapa langkah metode yang dipergunakan:

1. Observasi: metode ini digunakan untuk mendapatkan gambaran kehidupan orang dan masyarakat Jepang. Gambaran yang diperoleh merupakan bahan /data primer yang akan ditelaah

2. Wawancara: teknik ini dilakukan untuk mendapatkan gambaran yang lebih detail tentang bahan kajian. Wawancara dilakukan terhadap orang-orang Jepang, baik dosen maupun mahasiswa, atau sukarelawan berkebangaan Jepang.

3. Klasifikasi: setelah diperoleh bahan yang cukup dilakukan klasifikasi bahan baik dari segi urgenitas maupun dari segi jenis bahan/data.

4. Analisa: dilakukan analisa dilakukan atas bahan yang sudah diperoleh dan diperkuat bahan/informasi dari buku yang sudah ada.

5. Interpretasi: metode ini digunakan dengan melakukan interpretasi untuk mendapatkan pemahaman yang tepat terhadap bahan kajian, untuk mendapatkan ide-ide dasar dari bahan kajian, dan gambaran bagaimana bentuk penerapannya secara aktual

6. Sintesa: dari hasil kajian beberapa aspek yang sudah diteliti dan dikaji dengan menguunakan logika deduktif diperoleh siatu sintesa. Sintesa ini merupakan suatu sebagai kesimpulan yang menjawab permasalahan yang diajukan.

7. Deskripsi: semua bahan penelitian, kajian ilmiah, dan ujicoba penerapan,sampai pada kesimpulan akhir dideskripsikan dengan mempertahankan 


\section{PEMBAHASAN}

2.1. Model Pendidikan Karakter di Jepang dan Implementasinya dalam Kehidupan Masyarakat Jepang

Terbentuknya karakter unggul serta nilai-nilai khas budaya Jepang yang dimiliki bangsa Jepang hingga Jepang telah mencapai keadaan yang maju dan sejahtera adalah hasil dari usaha-usaha bangsa Jepang dalam masalah pendidikan, termasuk di dalamnya pendidikan karakter. Kalau berbicara tentang pendidikan karakter, maka yang dimaksud adalah segala usaha yang bersangkutan dengan mendidik orang tersebut agar mempunyai karakter unggul. Pendidikan karakter tidak hanya bisa dilakukan di lembaga formal seperti sekolah, tetapi bisa juga dilakukan dalam lingkungan non-formal seperti dalam keluarga maupun dalam masyarakat.

Bangsa Jepang menganut filsafat bahwa manusia dapat diubah keadaan dan sifatnya melalui usaha orang lain atau usaha sendiri. Mereka kurang atau bahkan tidak percaya bahwa manusia sudah sejak semula ditetapkan dalam keadaan tertentu yang tidak dapat diubah atau berubah. (Suryohadiprojo. 1987.210)

Dengan filsafat tersebut bangsa Jepang sangat mengutamakan pendidikan, termasuk pendidikan karakter. Berikut adalah penjelasan mengenai bagaimana pendidikan karakter di Jepang dilakukan serta implementasinya dalam kehidupan sehari-hari.

\section{Pendidikan Karakter di Lembaga Formal (Sekolah )}

Pendidikan Jepang terdiri atas sistem 6-3-3-4 dimana siswa wajib mengemban 6 tahun Sekolah Dasar (Shougakkou), 3 tahun Sekolah Menengah Pertama (Chuugakkou), 3 tahun Sekolah Menengah Atas (Koutougakkou), 4 tahun atau lebih untuk jenjang Perguruan Tinggi (Daigaku).

Pendidikan 9 tahun dari SD hingga SMP merupakan pendidikan wajib yang harus diikuti oleh setiap siswa yang ada di Jepang dimana pendidikan tersebut menjadi dasar-dasar pembentukan kepribadian, watak, perilaku. Pada Sekolah dasar siswa akan diajarkan mata pelajaran bahasa Jepang, pengenalan lingkungan hidup, musik, menggambar, olah raga, kerajinan tangan, pelajaran-pelajaran topik, ilmu-ilmu sains, aritmetika, dan sosial. Pada pelajaran mengenai ilmu sosial murid-murid Sekolah Dasar diajarkan pendidikan moral, berpartisipasi dalam aktivitas sosial dan kegiatan sosial lainnya.

Untuk siswa SMP diajarkan pendidikan bahasa Jepang, bahasa Inggris, bahasa Asing, ilmu-ilmu sosial, matematika, sains, musik, kesehatan, pendidikan jasmani, seni, industri, kesejahteraan keluarga, homemaking. Sama halnya dengan Sekolah Dasar, Pada pelajaran mengenai ilmu sosial siswa SMP diajarkan pendidikan moral, berpartisipasi dalam aktivitas sosial dan kegiatan sosial lainnya.

DARI:http://yardapoteker.wordpress.com/?s $=$ SISTEM+PENDIDIKAN+JEPANG.

Adapun Pendidikan karakter di Jepang diajarkan melalui pendidikan moral atau dalam bahasa Jepangnya disebut dengan doutoku yang diberikan pada setiap jenjang sekolah mulai dari SD sampai SMA. Melalui pendidikan moral atau pendidikan moral ini tercipta karakter bangsa Jepang yang terkenal sebagai bangsa yang ulet, pekerja keras, gigih, jujur, memiliki rasa toleransi, dan rasa kesetiakawanan yang tinggi. Pendidikan moral ini diintegrasikan ke dalam kurikulum pendidikan dan telah menjadi bagian tak terpisahkan dalam mata pelajaran lainnya.

Kurikulum pendidikan di Jepang terdiri atas tiga kategori: (1) mata pelajaran akademik (wajib dan pilihan), pendidikan moral, dan (3) kegiatan khusus. Pendidikan moral diberikan sebanyak 34 jam belajar pada tingkat awal, 35 jam pada tingkat kedua hingga 9 ( kelas 2 SD hingga 3 SMP). Hal ini mewakili 3,3-4,0\% dari total jam belajar setiap tahunnya dari tiap tingkat. Dengan kata lain, terdapat satu jam pelajaran (45 menit untuk SD dan 30 menit untuk SMP) pendidikan moral yang diberikan setiap minggunya. (Murni Ramli.2009) 
Kandungan pendidikan moral dibedakan menjadi empat area dengan total 76 item. Keempat area tersebut adalah:

1. Regarding Self, meliputi :

a. Moderation (pengerjaan mandiri dan melakukan "moderator life")

b. Diligence (bekerja keras secara mandiri)

c. Courage (pengejaan sesuatu secara benar dengan keberanian)

d. Sincerity (bekerja dengan sincerity and cheer)

e. Freedom and Order (nilai kebebasan dan kedisiplinan)

f. Self-improvement (pemahaman terhadap diri sendiri, mengubah apa yang seharusnya diubah, dan memperbaiki diri sendiri)

g. Love for Truth (mencintai dan mencari kebenaran, mencari dasar kehidupan dan bertujuan mencapai standar ideal).

(Murni Ramli.2009)

2. Relation to Others, meliputi:

a. Courtesy (pemahaman terhadap tata sopan santun, berbicara dan bertingkah laku tergantung pada situasi dan kondisi)

b. Consideration and Kindness (memperhatikan kepentingan orang lain, baik hati, dan empati),

c. Friendship (memahami, percaya dan menolong orang lain)

d. Thanks and Respect (menghargai dan menghormati orang-orang yang telah berjasa kepada kita, salah satunya dengan memberikan ucapan terima kasih)

e. Modesty (menghargai orang lain yang berbeda ide dan status melalui sudut pandang luas)

(Murni Ramli.2009)

3. Relation to the nature and the sublim with:

a. Respect for Nature (mengenal alam dan cinta kepada hewan dan tanaman)

b. Respect for Life (menghargai kehidupan dan makhluk hidup) c. Aesthetic Sensitivity (memiliki sensitivitas estetika dan perasaan terhadap kehidupan manusia).

d. Nobility (mempercayai kekuatan dan keunggulan manusia untuk mengatasi kelemahan diri, dan menemukan kebahagiaan sebagai manusia)

(Murni Ramli.2009)

4. Relation to Group and Society, meliputi:

a. Public Duty (menjaga janji dan menjalankan kewajiban dalam masyarakat, serta merasa kewajiban publik)

b. Justice (jujur dan tak berpihak tanpa diskriminasi, prejudice dan keadilan)

c. Group Participation and Responsibility (keinginan untuk berpartisipasi sebagai grup, menyadari perannya, melaksanakan tugas dan kewajiban dengan bekerja sama)

d. Industry (memahami makna bekerja keras, dan keinginan untuk bekerja)

e. Respect for Family Members (mencintai dan menghormati guru dan orang di sekolah/kampus, menciptakan tradisi sekolah yang lebih baik (kerja sama) )

f. Contribution to Society (menyadari kedudukannya dalam masyarakat setempat, hormat dan cinta terhadap mereka yang berkontribusi dalam masyarakat (senior citizens) )

g. Respect for Tradition and Love of Nation (tertarik kepada budaya dan tradisi bangsa, mencintai bangsa)

h. Respect for Other Culture (menghargai budaya asing dan manusianya, dengan menyadari kesadaran sebagai bangsa, dan menjalani persahabatan internasioanl.

(Murni Ramli.2009) 
Dari uraian di atas dapat diketahui bahwa pendidikan moral yang diterapkan di Jepang sangatlah rinci yang pada akhirnya dapat membentuk karakter orang Jepang yang khas.

Pada dasarnya yang paling menentukan keberhasilan pembentukan karakter masyarakat Jepang dalam lembaga pendidikan formal adalah ada pada implementasinya dalam kehidupan nyata para siswa. Pendidikan moral di Jepang tidak hanya diajarkan teorinya saja seperti pendidikan moral yang diajarkan di Indonesia, tetapi Jepang lebih mengutamakan realisasi dari pengajaran moral tersebut dalam kehidupan sehari-hari.

Pendidikan karakter di sekolahsekolah Jepang banyak diajarkan dalam bentuk praktek langsung. Pendidikan moral di sekolah-sekolah SD dan SMP di Jepang tidak diajarkan sebagai sebuah mata pelajaran khusus seperti di Indonesia, tetapi diintregasikan dalam semua mata pelajaran. Yang bertanggung jawab secara langsung adalah wali kelas. Pendidikan moral di Jepang diantaranya diajarkan dalam pelajaran seikatsu atau life skill atau pendidikan kehidupan sehari-hari. Dalam pelajaran itu siswa SD diajari tatacara menyebrang jalan, adab di dalam kereta, yang tidak saja berupa teori, tetapi guru juga mengajak mereka untuk bersama naik kereta dan memparktekannya. Wali kelas juga menyampaikan kasus pelanggaran dan mengajak siswa untuk mendiskusikan pemecahannya . ( Murni Ramli 2008)

Pendidikan moral di SD Jepang lebih mengutamakan praktek dalam kehidupan sehari-hari. Ramli dalam makalahnya yang berjudul Pendidikan Moral di Jepang menjelaskan, anak-anak kelas 1 SD hanya diajari perilaku sehari-hari yang ditemukan dilingkungannya, misalnya jika mereka sedang bermain, tiba-tiba tanpa sengaja memecahkan kaca jendela tetangga, apa yang harus mereka lakukan? Anak-anak diajarkan untuk segera minta maaf dan tidak boleh lari dari tanggung jawab. (Murni Ramli. 2006)

Anak-anak sekolah di Jepang wajib datang sepuluh menit sebelum sekolah dimulai. Hal ini untuk mengajarkan kedisiplinan. Bila ada pekerjaan rumah atau tugas lainnya siswa wajib mengumpulkan tugas tersebut tepat waktu. Untuk mengajarkan keteraturan dan kebersihan, anak anak sekolah disuruh untuk menata dan merapikan sandal dan sepatu di tempat yang telah disediakan sebelum memasuki kelas. Anak-anak sekolah juga dibiasakan buang sampah pada tempatnya, menyimpan kembali barang yang sudah digunakan di tempatnya semula.

Pendidikann karakater di Jepang juga diajarkan melalui metode learning by doing. Seperti misalnya makan siang bersama, bekerja sama dengan teman, mengucap salam, aktivitas motorik, dan berani tampil di depan kelas.

Salah satu contoh menarik yang mengajarkan tentang team work dan kepemimpina terlihat dari sistem keberangkatan siswa SD Jepang ke sekolah mereka. Siswa SD di Jepang diharuskan berjalan kaki ke sekolah, mereka berkumpul di pos masing-masing tiap-tiap wilayah secara berkelompok, tidak ada yang berjalan sendiri, saling menunggu dan akan berangkat apabila anggota kelompok sudah lengkap, mereka berjalan berbaris dipimpin anggota kelas 6 yang berjalan diurutan paling depan. Jadwal masuk pintu gerbang sekolah hanya 10 menit, dari pukul 7.508.00. Menariknya, kelompok pertama yang mencapai gedung sekolah tidak akan memasuki gerbang sekolah terlebih dahulu. Mereka berbaris rapi di depan gerbang menunggu kedatangan kelompok yang lainnya. Begitu kelompok terakhir datang, kelompok-kelompok tersebut memasuki pintu gerbang dengan barisan yang rapi, tidak berpencar, tanpa ada keributan, dan hanya membutuhkan waktu sekitar 10 menit. Meskipun dalam cuaca dingin bersalju, semua siswa tetap melakukannya dengan penuh semangat, rasa sabar yang tinggi dan tanpa berkeluh kesah.

Bangsa Jepang memahami betul bahwa pendidikan memegang peranan yang sangat penting pada masa pertumbuhan dan perkembangan anak-anak sebagai generasi penerus bangsa. Pendidikan sedari dini yang ditanamkan kepada siswa Jepang di sekolah dasar lebih ditekankan kepada pendidikan 
karakter dan pendidikan nilai-nilai moral. Sebagai contoh, dalam penyampaian pelajaran moral, tentang berbohong, pendekatan yang dilakukan oleh guru Jepang adalah tidak dengan mendoktrin tentang pentingnya untuk berlaku jujur, namun dengan mengajak anak anak berdiskusi tentang akibat-akibat berbohong. Tidak ada yang malu bertanya dan mentertawakan teman yang sedang bertanya, bahkan dalam menjawab pertanyaan guru pun, semuanya beradu cepat serentak mengacungkan tangan seraya meneriakan "haik" dengan lantang. Diskusi interaktif itu menggiring siswa untuk berfikir tentang pentingnya melaksanakan nilai-nilai moral yang diajarkan. Tidak ada proses menghafal, juga tidak ada tes tertulis untuk pelajaran moral ini. Untuk mengecek pemahaman siswa tentang pelajaran moral yang diajarkan, mereka diminta untuk membuat karangan, atau menuliskan apa yang mereka pikirkan tentang tema moral tertentu. Kadang mereka juga diputarkan film yang memiliki muatan moral yang akan diajarkan, kemudian mendidkusikan makna dari film tersebut.

Pendidikan karakter lainnya yang diterapkan di sekolah dasar di Jepang adalah pendidikan model Jepang yang disebut dengan tokkatsu yang bertujuan untuk membentuk pendidikan anak seutuhnya. (hole child education ). Pada program tokkatsu setiap pelajar terlibat aktif dalam kegiatan yang dirancang bersama-sama dimana semua anggota kelompok memiliki tugas masing-masing. Program ini berupaya menumbuh-kembangkan sikap spontanitas dalam melakukan kerja sama, misalnya melalui "act of cleaning", kegiatan membersihkan lingkungan. Dengan kegiatan ini pelajar akan menyadari pentingnya lingkungan yang bersih, resik dan rapi, sehingga mereka termotivasi untuk membersihkan lingkungan disekitarnya secara spontan.

Kegiatan kelompok ini dilakukan sesama rekannya dimana guru mengawasi dan bertindak sebagai fasilitator mendampingi mereka. Siswa belajar dengan sistem learning by doing. Kegiatan dan tugas-tugas diselesaikan bersama dengan pembagian tugas baik yang ditentukan bersama maupun atas pilihan sendiri. Pelajar yang menentukan sendiri kontribusinya dalam melaksanakan tugas bersama, dalam istilah bahasa Jepangnya disebut dengan "kakari". Melalui pendekatan ini pelajar diajarkan tanggung jawab menunaikan kewajiban yang telah ditentukannya sendiri. Misalnya program membersihkan sekolah, ada yang memilih untuk menyapu, mengepel lantai kelas, ada juga yang membersihkan toilet, kantin dan sebagainya. Demikian pula misalnya dalam kegiatan makan siang bersama sudah ditentukan siapa-siapa saja yang akan menghidangkan makanan hingga mencuci piring dan membersihkan meja, demikian seterusnya.

Siswa-siswa SD di Jepang sangat antusias dan serius dalam melaksanakan program tokkatsu ini. Sikap kerja telah terbentuk dengan baik membuat mereka melakukan pekerjaannya dengan sungguhsungguh. Nilai-nilai sosial, kerja sama dan sikap kebersamaan melekat pada diri individu pelajar Jepang dan sikap ini pun terbawa tidak hanya di ruang kelas atau di kompleks sekolah saja, tetapi telah terbiasa juga dilakukan di rumah dan lingkungan sosial di luar sekolah. Di sini tampak pelajar sadar akan pentingnya menyelesaikan tugas sosial secara bersama-sama di sekolah. Kerja sama positif seperti ini perlu dilakukan secara massif melalui penyadaran dan kebersamaan berbuat baik kepada sesama dalam bentuk kongkrit di sekolah.

Model tokkatsu ini telah berlangsung lama dan berhasil membentuk karakter bangsa Jepang yang bertanggung jawab, sehingga membawa negara Jepang menjadi salah satu negara maju di dunia.

Pendidikan karakter di lembaga formal di Jepang lebih diutamakan di tingkat SD dan SMP dengan menitik beratkan pada pendidikan moral yang diintregasikan dalam kehidupan nyata sehari-hari siswa. Adapun di tingkat SMA pendiidkan moral durubah menjadi pendidikan kewarganegaraan. Pendidikan prinsip dasar hidup yang kuat di masa pendidikan dasar inilah yang membuat kedisiplinan dan keteraturan dalam masyarakat Jepang. 


\section{PENDIDIKAN KARAKTER DI LEMBAGA NON-FORMAL}

Pendidikan karakter tidak hanya tidak hanya dilakukan di lembaga formal seperti di sekolah atau perguruan tinggi, tetapi dilaksanakan juga di lembaga nonformal seperti keluarga, masyarakat dan perusahaan. Berikut penjelasan mengenai pendidikan karakter di lembaga non-formal tersebut:

\section{Keluarga}

Keluarga memegang peranan penting dalam membentuk karakter seorang anak. Peran orang tua di Jepang sangat tinggi didalam mendidik anak-anaknya menjadi anak yang berkarakter. Sopan santun, kedisiplinan, keteraturan, sudah diajarkan sejak dini. Sistem pendidikan karakter tersebut dilakukan dengan memberi contoh langsung kepada anak-anaknya. Ketika mau makan misalnya orang tua mengajarkan anak-anaknya untuk duduk rapi di aa meja makan, sebelum makan mereka diajarkan mengucapkan " itadakimasu” sebagai etika umum yang dilakukan oleh orang Jepang pada saat akan makan, dan sesudah makan diajarkan pula mengucapkan gochsosamadeshita, sebagai bentuk ungkapan terima kasih kepada orang tua yang telah menyiapkan makanan. Begitu juga anak-anak diajarkan untuk menghabiskan makanan yang telah dimasukan ke dalam piring. Hal ini dilakukan untuk melatih anak agar menjadi pribadi yang tidak menyia-nyiakan sesuatu. Bila sudah selesai makan, anak-anak disuruh untuk mencuci piring sendiri piring dan gelas yang telah dipakai. Ini bertujuan agar anak-anak tidak tergantung pada orang tua dan bisa bersikap mandiri.

Dalam keluarga Jepang, yang memegang peranan paling penting dalam mendidik karakter anak adalah kaum ibu. Sistem pendidikan dan kebudayaan Jepang sepertinya sangat mengandalkan peran perempuan dalam membesarkan, mendidik dan mengajar anak-anak di luar sekolah. Karena itu di Jepang, dipegang teguh kebijakan "ryosai kentro", yang artinya " istri yang baik dan ibu yang arif". Yang menetapkan posisi perempuan selaku manajer urusan rumah tangga dan perawat anak-anak bangsa. Sejak dulu filosofi ini merupakan bagian dari pola pikir bangsa Jepang dan menjadi kunci pendidikan dari generasi ke generasi.

Dengan filosopi ini para ibu di Jepang mempunyai rasa tanggung jawab yang tinggi untuk mendidik anak-anak mereka menajadi anak yang bila sudah tumbuh dewasa akan berguna bagi bangsa. Oleh karena itu sejak usia dini, anak-anak mereka sudah dididik dan diajarkan tentang karakter-karakter positif seeprti kedisiplinan, keteraturan, kerja sama, kerja keras, mandiri dan karakter-karakter yang lainnya. Bahkan ada beberapa keluarga di Jepang yang sangat keras dalam mendidik etika anak-anaknya, Bila anaknya melakukan suatu perbuatan yang tidak sesuai dengan peraturan yang berlaku, orang tuanya tidak segan-segan untuk memberikan hukuman.

Penulis menyaksikan sendiri waktu berada di Jepang, ada seorng anak kecil yang dipukul kepalanya sampai menangis oleh bapaknya gara-gara anak tersebut membuang sampah sembarang. Hukuman tersebut akan memberikan efek jera bagi anak tersebut agar tidak mengulangi hal yang sama.

Kyoiku mama merupakan salah satu bentuk nyata dari peran perempuan dalam mendidik karakter anak-anak dalam keluarga Jepang. Kyoiku mama artinya pendidikan ibu, dimana seorang ibu dikasih tanggung jawab sepenuhnya untuk mendidik dan mengajar anaknya dalam hal pendidikan karakter dan etika. Kyoiku mama mulai berkembang di Jepang pada paruh kedua abad ke-20.

Perempuan Jepang berpendapat semakin sukses mereka mendidik anakanaknya menjadi orang yang berhasil di masyarakat, maka akan semakin tinggi juga penghargaan yang akan diberikan masyarakat kepada mereka. Keberhasilan seorang ibu di mata masyarakat dilihat dari keberhasilan anak-anaknya, baik sebagai warga, pemimpin maupun pekerja. Dengan sistem budaya seperti itu, maka para ibu di Jepang berlomba-lomba mendidik dan 
mengajar anak mereka agar menjadi orang yang sukses dan beguna bagi masyarakat dan bangsa.

Mengingat kyoiku mama mampu membina kehidupan keluarga yang relatif stabil, maka sekolah tidak perlu terlalu berkonsentrasi pada masalah pendidikan karakter seperti kedisiplinan dan yang lainnya, karena pada dasarnya pendidikan karakter seperti itu sudah diajarkan baik secara langsung maupun secara tidak langsung oleh orang tua siswa terutama oleh kaum ibu dalam keluarga masing-masing. Dengan demikian para guru di sekolah punya ketenangan dan waktu yang cukup untuk mengajarkan pengetahuan umum tanpa harus terpecah konsentrasinya untuk mengajarkan karakter.

Atribut dari sistem nilai di Jepang seperti kesahajaan, kerja sama, kedisiplinan, keteraturan, kerja keras, rasa malu, menghargai orang lain dan yang lainnya diajarkan dengan sungguh-sungguh dalam keluarga Jepang terutama oleh para ibu yang menganggap anak adalah "ikigai" dan aset yang sangat berharga untuk membawa nama baik keluarga di mata masyarakat.

Untuk nilai kesederhanaan, orang tua di Jepang mengajarkan anaknya tidak menggunakan uang untuk hal yang tidak perlu. Hal ini untuk mengajarkan kesederhanaan. Orang tua di Jepang tidak membelikan anaknya motor atau mobil untuk berangkat ke sekolah. Orang Jepang lebih terbiasa naik sepeda atau kereta api untuk berangkat ke sekolah. Anak-anak di Jepang dikasih uang jajan tidak berlebihan. Kadang-kadang uang jajan tersebut oleh anaknya tidak digunakan untuk jajan melainkan ditabung untuk keperluan yang lain.

Para orang tua di Jepang mengajarkan anak-anak mereka kedisplinan dari hal-hal yang paling kecil, seperti mengajarkan mereka untuk menyimpan sesuatu pada tempatnya semula. Selalu mengajarkan mereka untuk selalu tepat waktu pada saat makan malam bersama, jam tidur dan jam bangun, jam masuk ofuro, jam nonton tv, jam bermain. Bila ada yang melanggar peraturan tersebut, orang tua memnberi peringatan atau hukuman kecil agar anaknya tidak melakukan hal seperti itu. Etika - etika yang lainnya seperti mengucapkan salam ketika keluar rumah dan kembali dari bepergian, mengucapkan terima kasih saat dibantu, mengucapkan maaf saat melakukan kesalahan dan memperbaiki kesalahan, diajarkan dengan sungguh-sungguh dalam keluarga Jepang.

Keluarga sebagai lingkungan pembentukan watak dan pendidikan karakter pertama dan utama memainkan peranan yang sangat signifikan dalam membentuk karkater-karakter bangsa Jepang. Orang tua di Jepang sadar bahwa pendidikan karakter anak merupakan tanggung jawab utama mereka, bukan tanggung jawab utama sekolah tempat anak mereka sekolah, atau tanggung jawab masyarakat di mana mereka tinggal. Dengan kesadaran seperti ini, para orang tua di Jepang dengan sungguhsungguh mendidik dan mengajarkan anaknya moral, etika dan perilaku yang sesuai dengan norma-norma yang berlaku di masyarakat Jepang pada umumnya.

\section{Masyarakat}

Pendidkan karakter dalam amsyarakat Jepang tidak terlepas dari akar sejarah prinsip hidup samurai yang disebut dengan bushido yang telah tertransformasi dan menjadi watak dasar dan prinsip hidup masyarakat Jepang pada umumnya. Berdasarkan sumbernya, nilai-nilai bushido berasal dari ajaran Budha dan Shinto. Bushido yang telah menjadi prinsip hidup orang Jepang berisikan ajaran tentang kesetiaan, kejujuran, etika sopan santun, tata krama, disiplin, rela berkorban, kerja keras, kebersihan, hemat, kesabaran, ketajaman berfikir, kesederhanaan, serta kesehatan jasmani dan rohani.

Bushido pada awalnya merupakan kode etik kepahlawanan kaum samurai dalam feodalisme Jepang. Samurai adalah sebuah strata sosial penting dalam tatanan feodalisme Jepang. Biasanya para samurai dan Shogun rela mempertaruhkan nyawa demi kemenangan. 
Bushido menjadi asas moral yang harus dihayati kalangan ksatria. Bushido juga menjadi pengganti pelajaran agama dan pedoman moral serta etika bangsa Jepang. Tidak heran jika nilai-nilai bushido sangat terpatri dalam jiwa bangsa Jepang hingga saat ini.

Dengan semikian, dapat dikatakan di masa sekarang ini tidak ada pendidikan karakter khusus dalam masyarakat Jepang, karena karakter mereka sudah terbentuk sejak dahulu kala dengan mentransformasikan ajaran-ajaran bushido dalam kehidupan mereka sehari-hari. Norma masyarakatlah yang menjadi hukum sosial yang mengontrol kehidupan masyarakat dalam masalah moral dan beretika. Orang Jepang di zaman sekarang ini, terutama anak-anak mudanya banyak yang tidak menganut satu agama tertentu, meskipun demikian, sikap jujur, menghormati orang lain, disiplin dan lainnya ada dalam pribadi mereka. Bila kita kehilangan barang apapun di Jepang, bila yang menemukannya orang Jepang niscaya barang itu akan diserahkan ke pemiliknya atau diserahkan kepada polisi agar yang punya bisa segera menemukannya. Begitu juga budaya menghormati orang lain terlihat dari sikap orang Jepang yang berusaha untuk tidak mengganggu kenyamanan orang lain di tempat umum dengan bersikap sopan dan mematuhi etika yang berlaku.

Agar norma msyarakat di tempat umum bisa terjaga dengan baik, salah satu upaya yang dilakukan pemerintah dalam pendidikan karakter masyarakat Jepang misalnya di setiap sudut di negara Jepang dipasang poster-poster yang memberikan pesan agar seluruh masyarakat Jepang bersikap sopan, saling menghargai, disiplin, taat hukum, dan yang lainnya. Di kota-kota juga sering terlihat poster yang mengisyaraktkan ketidaksopanan dalam kereta api. Poster tersebut dipasang agar masyarakat tidak mencontoh hal tersebut karena bisa mengganggu kenyamanan umum.. Ada juga poster yang menggambarkan seorang siswa SMA yang duduk dengan kaki mengangkang mengambil tempat yang lebar dan tas besarnya diletakan di depan sehingga menghalangi orang untuk berdiri bebas. Gambar lain tentang seorang gadis yang berbicara melalui telepon genggam dengan suara keras sehingga mengganggu penumpang lain. Tidak hanya poster, kendaraan umum di Jepang sangat terkenal sepenuh dengan peringatan dan ajakan untuk mematuhi norma-norma, misalnya larangan untuk menelepon, berbicara keras, dan beberapa tindakan yang mengganggu. Acara tv swasta di Jepang pun sarat nilai pendidikan disamping tidak melupakan unsur hiburan. ( Murni Ramli.2008).

Pendidikan karakter dalam masyarakat Jepang juga dicontohkan oleh para pejabat yang memegang kekuasaan. Bila ada pejabat yang merasa gagal atau melakukan tindakan yang merugikan negara, mereka akan segera mengakui kesalahan tersebut dan segera mengundurkan diri dari jabatannya. Ini mendidik masyarakat agar memiliki budaya malu dan budaya berani mengakui kesalahan apabila berbuat salah.

Semangat bushido yang telah terpatri hingga kini dalam kehidupan masyarakat Jepang serta kesadaran sangat mendalam dari setiap warga Jepang dalam mentaati semua peraturan yang berhubungan dengan norma-norma masyarakat telah menjadikan Jepang menjadi negara yang aman, tertib dan sadar moral. Semangat bushido yang telah menjiwai kaum samurai selama beberapa abad itu, sampai kini masih hidup, namun bukan dalam bentuk semangat untuk berperang atau mengabdi kepada komandan. Semangat bushido yang telah menghidupkan dan mengembangkan ekonomi dan industri Jepang adalah semangat berdisiplin tinggi, bekerja keras, bertanggung jawab dan punya rasa malu bila melakukan perbuatan yang merugikan orang lain.

\section{Perusahaan}

Etos kerja masyarakat Jepang yang sangat tinggi. Bahkan hal tersebut dicontoh oleh negara-negara lain yang ingin negaranya maju seeprti Jepang. Karakter masyarakat Jepang adalah tipikal pekerja keras, pantang menyerah, dan perfectionist dan sangat profesional demi memberikan yang terebaik untuk perusahaan atau tempat mereka bekerja. Salah satu karkater yang 
menonjiuol dalam dunia kerja masyarakat Jepang adalah sikap profesiona mereka dalam bekerja. Profesionalitas yang tinggi dan kecintaan mereka terhadap pekerjaannya, membuat mereka benar-benar mengabdikan hidup mereka untuk pekerjaan, bahkan tidak sedikit yang rela lembur tanpa digaji. Hal ini tidak lain karena mereka ingin memberi kontribusi yang terbaik untuk perusahaannya.

Para pekerja di perusahaan Jepang terkenal dengan loyalitasnya yang sangat tinggi terhadap perusahaan di mana mereka bekerja. Selain itu mereka juga terkenal memiliki budaya kerja yang sangat tinggi, menghargai pekerjaan dan menjadikan pekerjaan sebagai bagian kehidupan mereka. Itulah sebabnya mereka sangat bertanggung jawab terhadap pekerjaan. Mereka juga sangat menghargai waktu, bergerak gesit dan berjalan dengan cepat.

Jepang terkenal dengan perusahaanperusahaan raksasa yang telah membuat produk yang dipasarkan ke seluruh dunia dan mendapat kepercayaan nomor satu dari segi kualitas. Sesudah Perang Duni II, perusahaan Jepang membentuk tiga sistem yaitu:

1. Sistem ketenagakerjaan sepanjang hidup, yakni perusahaan biasanya tidak memutus hubungan kerja.

2. Sistem kenaikan gaji sejajar umur, yakni perusahaan menaikkan gaji pekerjanya tergantung umur mereka.

3. Serikat pekerja yang diorganisasi menurut perusahaan, yakni berbeda dengan pekerja yang diorganisasi menurut jenis kerja, semua pekerja sebuah perusahaan, jenis pekerjaan apapun, diorganisasi dalam satu serikat pekerja. (Susilo.2010.56)

Dengan ketiga sistem ini pekerja menganggap kuat dirinya sebagai anggota perusahaan dan harus loyal kepada perusahaan. Di atas ketiga sistem inilah etos kerja dan budaya kerja orang Jepang dikembangkan.

\section{Terbentuknya}

karakter-karakter pekerja keras, disiplin. loyalitas tinggi, bertanggung jawab, sifat profesional yang terbentuk dalam pribadi para pekerja di perusahaan Jepang ada hubungannya dengan prinsip hidup Bushido yang ditarnsformasikan dalam perusahaan perusahaan Jepang. Nilai-nilai bushido yang diterapkan dalam perusahaan Jepang terwujud dalam prinsip $5 \mathrm{~S}$ di perusahaan Jepang yaitu: seiri yang artinya ringkas, seiton yang artinya rapih, seisou yang artinya resik, seiketsu yang artinya rawat dan shitsuke yang artinya rajin. Berdasarkan prinsip $5 \mathrm{~S}$ inilah manajemen perusahaan mendidik karakter para pekerjanya untuk selalu menerapkan prinsip $5 \mathrm{~S}$ ini pada saat bekerja di perusahaan.

Salah satu jenis pendidikan karakter yang dilaksanakan di perusahaanperusahaan Jepang adalah sebelum pekerjaan dimulai selalu diadakan meeting besar dan meeting kecil. Pada saat meeting besar bucho atau manajer selalu mengingatkan anak buahnya untuk selalu bekerja dengan giat, rajin, disiplin, penuh semangat, bertanggung jawab, kerja sama dan selalu menerapkan prinsip $5 \mathrm{~S}$. Para karyawan akan menyimak dengan baik dan penuh perhatian apa yang disampaikan oleh manajer mereka. Sebelum pekerjaan dimulai mereka melakukan senam ringan untuk sebagai pemanasan agar badan menjadi bugar.

Setelah meeting besar dilakukan juga meeting kecil dimana dalam meeting kecil tersebut diperinci lebih tegas lagi apa yang harus dikerjakan hari itu, diingatkan kembali tentang etika kerja yang berhubungan dengan tanggung jawab kerja, kerapihan, kedisiplinan, semangat kerja, keselamatan kerja dan etika yang lainnya yang mengacu kepada prinsip $5 \mathrm{~S}$ yang dijelaskan sebelumnya.

Pendidikan karakter para pekerja di perusahan pun dilakukan pada saat masa training setelah perekrutan dilakukan. Bagi mereka yang diterima bekerja diperusahaan akan diberikan training atau pelatihan selama dua minggu atau lebih tergantung perusahaannya, dengan tujuan untuk mengenalkan serta memberi pelatihan 
tentang sistem kerja serta mengajarkan sikap kerja yang baik serta, mengenalkan peraturan-peraturan perusahaan dan yang paling penting menumbuhkan rasa cinta juga loyalitas terhadap perusahaan tersebut.

Pada masa training tersebut para karyawan baru akan dididik dan ajarkan tentang sikap profesionalisme, loyalitas, tanggung jawab, kedisiplinan, kerapihan, keteraturan yang mengacu kepada prinsip 5 S. Melalui training tersebut para pekerja baru akan memperoleh pengetahuan yang mendalam tentang sikap kerja yang dibutuhkan dan harus dilakukan pada saat mereka bekerja di perusahaan tersebut.

\section{PENUTUP}

Keberhasilan Jepang dalam membangun negaranya menjadi negara yang maju dalam berbagai bidang kehidupan selain didukung nilai-nilai khas budayanya juga didukung oleh sumber daya manusia yang mempunyai karakter unggul yang diperoleh dari hasil pendidikan karakter baik dilembaga formal maupun non formal.

Suka bekerja keras, mempunyai semangat belajar yang tinggi, sangat disiplin, budaya malu, kebersamaan yang sangat kuat, sikap penatng menyerah, hemat, jujur, patriotik, menjaga tradisi budaya sendiri merupakan beberapa karakter dan nilai budaya Jepang yang sangat terkenal dan menjadi jati diri bangsa Jepang di mata dunia.

Banyak faktor yang membentuk karakter-karakter tersebut, salah satunya adalah prinsip hidup samurai yang terkandung dalam ajaran bushido yang ditarnsformasikan dalam kehiduapm masyarakat Jepang sehari-hari. Selain itu pendidikan karakter yang dilaksanakan baik di lembaga formal maupun lembaga non formal juga memegang peranan penting dalam membentuk karakter unggul orangorang Jepang.

Di lembaga formal mulai dari tingkat SD sampai tingkat SMU pendidikan karakter diajarkan melalui mata pelajaran moral (doutoku) yang diintregasikan ke seluruh mata pelajaran yang diajarkan di sekolah. Pelajaran moral tidak hanya sekedar diajarkan teorinya saja, melainkan lebih banyak diajarkan praktek serta penerapan dari ajaran moral tersebut dalam kehidupan sehari-hari.

Di lembaga non formal, pendidikan karakter diajarkan di keluarga, masyarakat serta perusahaan. Dalam keluarga yang memegang peranan penting dalam mengajarkan karakter adalah ibu. Pendidikan ibu (Kyoiku mama) merupakan salah satu program yang cukup berhasil dalam mendidik karakter seorang anak dalam keluarga, dimana dalam program tersebut seorang ibu di Jepang diberi tanggung jawab yang sangat besar untuk mendidik anaknya menjadi seorang yang berhasil dalam masyarakat yang mempunayi karakter unggul yang bermanfaat bagi masyarakat dan negara.

Adapun pendidikan karakter dalam masyarakat Jepang lebih mengacu kepada penanaman kedisiplinan agar masyarakat patuh hukum, tidak melanggar norma dan aturan yang berlaku dalam masyarakat. Untuk itu pemerintah banyak memasang poster-poster atau gambar-gambar yang mendorong masyarakat agar mempunyai karakter baik, disiplin, mempunyai budaya malu dan bertanggung jawab. Para pejabat di Jepang memberi contoh dan ketauladanan dalam hal mendidik masyarakatnya agar mempunayi karakter yang baik. Bila ada pejabat yang melanggar aturan negara serta merugikan masyarakat umum mereka tidak segan untuk segera mengundurkan diri tanpa menunggu pemecatan.

Pendidikan karakter pun dilakukan di perusahaan-perusahaan Jepang sehingga perusahaan-perusahaan Jepang mempunyai pekerja yang rajin, disiplin, bertanggung jawab, mempunyai loyalitas yang sangat tinggi. Pendidikan karakter di perusahaan Jepang dilakukan secara langsung pada saat training maupun secara tidak langsung pada saat bekerja setiap hari dengan mengacu kepad prinsip $5 \mathrm{~S}$ yang menjadi ciri khas dari perusahaan Jepang. 


\section{DAFTAR PUSTAKA}

Befu, Harumi.1981. Japan: An

Antropological Introduction. Tokyo:

Charles E. Tuttle Co.

Danandjaja, James.1997. Folklor Jepang :

Dilihat dari Kacamata Indonesia.

Jakarta: Pustaka Utama Grafiti.

Kawada, Kan. 1996. Atarashii Shakai

Rekishi. (Sejarah Masyarakat Baru)

Tokyo: Tokyo Shoseki

Nihongo Kyouiku Gakkai,1988.Nihon Jijoo

Shiriizu Nihon no Rekishi.

(Pengantar Sejarah Jepang).Tokyo:

Bonjinsha.(terjemahan dalam bahasa

Indonesia diedit oleh I Ketut

Surajaya).

Nitobe, Inazo. 2008. Bushido Jiwa Jepang

Surabaya : Era Media Publisher

Nasution, S. 1995 Berbagai Pendekatan dalam Proses Belajar Mengajar.Jakarta. Bumi Aksara.

Ramli, Murni.2006. Pendidikan Moral di Jepang,http://murniramli.blogspo t.com/,diunduh 15 Mei 2014
Ramli,Murni.2009. Pendidikan Moral orang Jepang http://murniramli.wordpress.com/ 2009/01/03/pendidikan moral orang Jepang ,diunduh 15 Mei 2014

Ramli, Murni.2009. Konsep Pembaharuan Kurikulum di Jepang ,http://indosdm.com.diunduh 17 Mei 2014

Suryohadiprojo, Sayidiman. 1987 Belajar Dari Jepangl.Jakarta. UI Press

Susilo, Taufik Adi. 2010. Spirit Jepang Jogjakarta. Ae-Ruz Media Grup

Tukiyo, 2012. Sistem Pendidikan dan Pendidikan Karakter di Jepang Serta Perbandingannya Dengan di Indonesia. FKIP. Universitas Widya Dharma Klaten

Tatang. 2012 Pendidikan Karakter di Jepang dan Indonesia. Makalah: Disampaikan dalam "Seminar Nasional dan Workshop Pembelajaran Bahasa arab Berbasis Karakter" di Bandung, 11 November 2012.

http://yardapoteker.wordpress.com/? $\mathrm{s}=\mathrm{SISTEM}+\mathrm{PENDIDIKAN}+\mathrm{JEPANG}$ 